\title{
EDITORIAL
}

\section{TRATAMENTO DA HANSENÍASE COM POLIQUIMIOTERAPIA PADRÃO OMS COM DURAÇÃO} FIXA

O Brasil ocupa o segundo lugar no mundo e o primeiro das Américas em número absoluto de portadores de hanseníase.

Em 1994, foram registrados 158.334 casos de hanseníase no Brasil, com taxa de prevalência de 10,50 doentes por 10.000 habitantes, considerada alta segundo os parâmetros da Organização Mundial de Saúde ( $\geq 5$ casos por 10.000 habitantes). Ainda nesse ano, foram detectados 32.793 casos novos, com taxa de detecção de 21,47 casos por 100.000 habitantes, considerada alta, segundo o parâmetro nacional ( $\geq 10$ casos por 100.000 habitantes).

Esta situação tem sido alvo da preocupação do governo brasileiro, exigindo esforços dos profissionais de saúde para o controle e eliminação da endemia como problema de saúde pública, ou seja, reduzir a prevalência a 1 caso por 10.000 habitantes atè o ano 2000 (meta da Organização Mundial de Saúde, estabelecida e acatada pelos países endêmicos durante a $44^{a}$ Assembléia Mundial de Saúde em 1991).

A estratégia da introdução, em 1986, e expansão para a rede de serviços de saúde, a partir de 1991, de um novo esquema terapêutico, a poliquimioterapia padrão OMS (PQT/OMS) de curta duração, têm possibilitado ao Brasil, em curto espaço de tempo, a redução de suas taxas anuais de prevalência (18,5/10.000 habitantes, em 1990 para 10,37 em 1994), aproximando-se da meta estipulada para o ano 2000.

O paciente obtém alta por cura ao completar as doses preconizadas pelo esquema PQT/OMS, não necessitando ficar sob vigilância do serviço de saúde.

Pacientes paucibacilares são tratados com 6 doses de PQT/OMS em até 9 meses e os multibacilares com 24 doses em até 36 meses, desde que não ocorram 3 faltas consecutivas para os paucibacilares e 4. para os multibacilares, o que implicará em reinício do tratamento.

A presença de episódios reacionais não impede a alta por cura. O mesmo se aplica para a presença de seqüelas.

Recebido para publicação em 02/12/94

\section{TREATMENT OF LEPROSY WITH WHO'S STANDARD FIXED DURATION POLYCHEMOTHERAPY}

Brazil holds the second place in the world and the first one in the Americas for the absolute number of leprosy's carriers.

In 1994, 158,334 cases of leprosy were registered in Brazil, with a prevalence rate of 10.50 patients per 10,000 inhabitants. According to the World Health Organization's parameters ( 25 cases per 10,000 inhabitants), this rate is a high one. Still in this year, 32,793 new cases were detected at a detection rate of 21.47 cases per 100,000 inhabitants, this being considered high accordingly to the national parameter ( 210 cases per 100,000 inhabitants).

This situation has been a target of the Brazilian government's concern. It requires health professional effort to control and eliminate this endemic disease as a public health problem, that is to reduce the prevalence to one case per 10,000 inhabitants by the year of 2000, (a World Health Organization objective, worldwide established during the $44^{\text {th }}$ World Health Assembly in 1991 , and followed by the countries with epidemics).

With the strategy of introducing a new therapeutic schedule in 1986 and its unfolding to the health service net from 1991 on, the WHO standard polychemotherapy (WHO/PCT) of short duration made it possible for Brazil, in a short period of time, to reduce the annual prevalence rates (from 18.5/10,000 inhabitants in 1990 to 10.37 in 1994), thus reaching the purpose stipulated for the year of 2000.

The patient is discharged from hospital by cure once completed the doses recommended by the WHO/PCT schedule, and he does not need stay under the public health service's surveillance.

Paucibacillary patients are treated with 6 doses of WHO/PCT in up to 9 months, and the multibacillary ones with 24 doses in up to 36 months, provided that three consecutive abscences do not occur regarding the paucibacillary patients and four concerning those multibacillary ones

The presence of reactional episodes does not hinder the discharge by cure. The same procedure is applied to the presence of sequelae.

At the end of 24 doses, the multibacillary patient may present positive bacilloscopy with fragmented bacilla, that is, unable to 
Editorial. Penna GO. Tratamento da hanseniase com poliquimioterapia padrão OMS com duração fixa. Revista da Sociedade Brasileira de Medicina Tropical 28:167-168, jul-set, 1995.

Ao final das 24 doses, o paciente multibacilar poderá apresentar baciloscopia positiva com bacilos fragmentados, ou seja, sem poder de multiplicação e de transmissão da doença, o que também não impede a alta por cura, visto que a eliminação de restos bacilares não guarda relação com a duração da quimioterapia e sim com a imunologia do indivíduo.

Visando o cumprimento da meta de eliminação da hanseníase como problema de saúde pública até o ano 2000, o governo brasileiro assinou e publicou em Diário Oficial a resolução $n^{\circ} 133$ de 01/09/94, que mantém a "priorização técnico-financeira ao Programa de Controle e Eliminação da Hanseníase para o período 1995-2000".

Além disso, a Coordenação Nacional de Dermatologia Sanitária, que em nível nacional coordena as ações de controle da hanseníase, já tem as diretrizes do Plano de Eliminação da Hanseníase para o período acima citado que consiste no diagnóstico precoce, o tratamento dos casos com PQT/OMS, com redução do índice de abandono e a prevenção de incapacidades fisicas.

O Brasil não tem medido esforços no sentido de reverter a atual situação da hanseníase no país, no entanto, só com a participação de todos os segmentos da sociedade o país conseguirá sair desta incômoda posição mundial em relação à hanseniase.

Neste sentido, realizou-se reunião, no dia 25 de maio de 1995, em Brasília, na qual foi assinada a "Declaração de Brasília" que ratifịca o compromisso e a parceria no cumprimento da meta de eliminação, envolvendo Ministério da Saúde, as unidades federadas e organizações nacionais $e$ internacionais. São signatários deste documento o Ministério de Estado de Saúde, o Presidente da Fundação Nacional de Saúde (FNS), o Diretor do Centro Nacional de Epidemiologia (CENEPI), treze secretários de Estado da Saúde, o Presidente da Sociedade Brasileira de Dermatologia (SBD), a Presidente da Associação Brasileira de Pós-graduação em Saúde Coletiva (ABRASCO), o Diretor do Programa de Ação para Eliminação da Hanseníase da Organização Mundial da Saúde (OMS) e o representante da Organização Pan-Americạna da Saúde no Brasil. multiplicating and transmitting the disease, which does not hinder the discharge by cure, since the elimination of bacillary residues is not related to the duration of chemotherapy but with the individual immunology.

Aiming at the accomplishment of the purpose of eliminating leprosy as a health problem, up to the year of 2000, Brazilian government signed and published in the Diário Oficial the resolution nr. 133 dated of $1^{\text {st }}$ September, 1994, which supports the "priority of technical and financial performance of the Leprosy Control and Elimination Program for the period 1995-2000".

Besides, the Sanitary Dermatology National Co-ordination which, at nationwide level, coordinates the leprosy control, does have the Leprosy Eliminating Program for the above mentioned period. Such program consists in the early diagnosis, treatment of the cases with WHO/PCT with reduction of giving up rate, and prevention from handicaps.

Brazil has worked to the utmost of its power in order to reverse the present situation of leprosy in the country. Nevertheless, only with the participation of all the segments of the society, it will be possible for Brazil to get out of this world-wide disagreable position in relation to leprosy.

On this purpose a meeting was held on May 25, 1995, in Brasília, when members of several Goverment organs, such as Ministry of Health, federate units and both national and international organizations signed the Brasilia's Declaration. This document rectifies the compromise and partnership for the accomplishment of leprosy elimination goal. The so called Brasilia Declaration was signed by the Minister of Health, the President of Health National Foundation (FNS), the Director of National Epidemiology Center (CENEP), thirteen Health Secretaries of State, the President of Brazilian Society of Dermatology (SBD), the President of Brazilian Association of Post-Graduation in Collective Health (ABRASCO), the Director of World Health Organization (WHO) Action Programme and also the Representative of Pan-American Health Organization (PAHO) in Brazil.

Gerson Oliveira Penna

Centro Nacional de Epidemiologia

Fundação Nacional de Saúde

Ministério da Saúde

Brasilia, DF. 